\title{
The Aftermath of Globalization on African Identity
}

\author{
Bonachristus Umeogu \\ Department of Philosophy, Faculty of Arts, Nnamdi Azikiwe University, Awka, Nigeria \\ Email: ojiakor99@yahoo.com
}

Received August $6^{\text {th }}$, 2012; revised September $10^{\text {th }}$, 2012; accepted September $23^{\text {rd }}, 2012$

\begin{abstract}
The rope nations and people have held on in order to climb up to a better life, is now threatening to draw them back into a pit of oblivion. What will it profit a nation to become civilized and lose its identity in the process? How will people of today look in the face of future generation and fumble at excuses to explain why they are not regarded as a cultural group of its own? This paper tries to show how globalization has led to the loss of cultural identity in Nigeria.
\end{abstract}

Keywords: Culture; Identity; Globalization; Identity Loss

\section{Introduction}

Anthony Giddens saw globalization as the intensification of worldwide social relations which links distant localities in such a way that local happenings are shaped by events occurring many miles away and vice versa. That is to say that globalization is a compressing and unifying force that binds the world together. Be that as it may, there is more to globalization than meet the eyes. No matter how promising the prospects of globalization looks or appeals to a nation, there is always a price. In some cases, morality or ethics might be the price. However, most often than not, the price is loss of identity amongst other. If a nation loses its identity, what does it become? This paper tries to mirror how globalization results to loss of identity.

The position of this paper does not contest the fact that globalization has upgraded the life of countries and nation. This paper through review of articles will explore the areas that globalization in the course of bettering the lives of people have resulted in the loss of cultural identities and heritage.

There are so many concerns of globalization as it affects education, politics, sports, economy and even information. That notwithstanding, this paper tries to look at globalization as it affects cultural identity of a developing country like Nigeria.

\section{Globalization}

From time immemorial, man has always evolved some form of interaction with his surroundings. Man as a social being has always had the need to interact with others and with his/her environment at large. By nature, man has also been a curious being with the insatiable need of knowing about neighbors. It is then of little wonder why he is seen as a social animal. Again, man's needs are insatiable which had led to a form of dependency and interdependency among men. Globalization stepped into the gap to address man's insatiable thirst.

By way of explanation, Wikipedia sees it or refers to globalization as the "process or processes of international integration". In the process of interaction between nations and countries; ideas, religions, language, arts, and other aspects of culture are interchanged, upgraded or modified.

Who would have ever imagined that the existence and relevance of traditional modes of communication will ever be threatened by the modern media? How did English language become the official lingua franca of many countries including Nigeria? How was Christianity introduced into a highly traditional society like Nigeria? There are so many "how's", but all has one answer which is through civilization that came through globalization.

Coming to definition of globalization, it has many operational definitions as there are researchers because each person defines it within the context of his/her study. That notwithstanding, we will try to look at some definitions.

Roland Robertson (1992) saw globalization as the "compression of the world and the intensification of the consciousness of the world as a whole". In a similar vein, Albrow \& King (1992) saw it as "all those processes by which the peoples of the world are incorporated into a single world society".

For Dukor (2010: p. 135), globalization ideally,

Is the philosophy of a cosmopolitan city that benefits all races; no center and periphery nations, where every race match up and down without fear or favour in the global ways and village. He also saw it as a process by which a network of cultural, political and economic advantages and interests of different peoples of the world work naturalistically for their mutual benefit.

In all the definitions, one striking similarity that can be deduced from them is that globalization is the manifestation of the global village predicted by Marshal McLuhan in 1964. That is, it is the overall result of miniaturizing, summarizing and compressing the world into McLuhan’s "global village”. If not how else will you explain a scenario where,

Business people on different continents now engage in electronic commerce; television allows people situated anywhere to observe the impact of terrible wars being waged far from the comfort of their living rooms; academics make use of the latest video conferencing equipment to organize seminars in which participants are located at disparate geographical locations; the Internet allows people to communicate instantaneously with each other notwithstanding vast geographical distances separating them, Scheuerman (2010). 


\section{Identity}

As regards identity, globalization has contributed to the alienation of individuals from their traditions. Identity here is all about cultural identity; what distinguishes one culture from another. It can be seen as the traits, characteristics, qualities, beliefs that make a group stand out among many. Ogugua 2007 in Ogugua \& Oduah (2007: p. 5) submitted that "culture is a mark of identity; it separates man from the animals and at the same time divides societies ... globalization distorts the culture, changing people's pattern of editing, dressing, talking etc."

Capturing this was Dukor who poignantly asserted that,

... in globalization, the identity of minority ethnic groups among nations is as important as the identity question of races among races ... In a globalized world, ethnic identity is mostly one unique element that is usually under threat. All ethnic groups, be it so called majority or minority, easily identify their ethnicity by their cultural values which are sacrosanct to them. In other words, ethnic group identities find meaning in their cultural forms, social situation, history and kinship system that make up their social intercourses Dukor (2010: p. 140).

Culture distinguishes a group of people from others. It is so unique to a group that it is meant to be guarded jealously. It is that "thing" that will make you say that; this person speaks like a South African or she dresses like an Igbo woman. By way of definition, Umeogu \& Ojiakor (2012) saw "Culture as the customs, beliefs, art, music, and all other products of human thought made by a particular group of people at a particular time. This culture is what distinguishes one culture from another, or a kind of identification which when exhibited reveals or gives inkling to where you came from”. Can the African cultural identity stand in the face of cultural globalization?

\section{Globalization and Cultural Identity}

To address the Socio-cultural impacts of globalization on national identity, I must say that it is two legged in that one cannot eat one's cake and still have it. Every society that has been touched by globalization has had its identity changed either positively or negatively. National identity according to Burton is "the shared beliefs and behaviours of a group, which form the basis for creating meaning for the persons who count themselves to be a part of the culture".

One of the impacts and which happens to be the thrust of this paper is that people have become confused of who they really are. They have confused their beliefs with the western ones and the behaviors of foreign countries have become the yardstick for measuring acceptable and current behaviors. The bitter truth is that our culture and its identity have been lost under the overwhelming influence of foreign culture. Foreign here means cultures that were not adopted from other African countries that have similarity in ways of life.

Most if not all cultures have been undergoing changes within the context of the current variety of globalization, so the likelihood of cultural change within the range of just the culture's needs is quite remote. There has been a drastic change in the mode of dressing, the popular language of communication, eating habits, and to the extent of sexuality. These changes have been either in the negative or positive. There are forms of dressing that identify a particular country like the Indian sari, the South African skin, the Igbo wrapper and what have you. Nowadays, jeans, pants and suits have replaced all this. There has been a mix up that in some cases, it is the skin colour that tells people apart.

Also, there is technological advancement especially in the area of communication, connectedness. According to Burton, "The main tool for the transfer of cultural values from one country or location to another is through various communication channels such as the media, the internet, other telecommunication tools and trade".

To contextualize it, globalization has given minorities a sense of belonging in the sense that one can be here and be updated of what is happening there. Again, physical contacts have been heightened because travelling especially by air has been made affordable even to the common man who wants to experience the world from above. Globalization has also helped people to relax in the sense that people have come to realize that life is managed. This has led to a situation where people go on vacations to unwind and destress for a longer and healthier life. Be that as it may, let us concentrate on the effect on cultural identity.

Coming to globalization and cultural identity proper, one may say that Globalization has had disastrous consequences on the governments and people of the African continent. We begin this section with the words of Dukor (2010: p. 135) that, "there has been a historical erosion of African identity and authenticity through the process of colonialism, neo colonialism and imperialism". That is, there is the tendency of loss of cultural identities by the one thing that is meant to work for us.

With regards to the relationship between globalization and identity loss, Ugwueye submits that,

Africans risk losing their cultural heritage in the face of globalization, not because their heritage is obsolete or inferior but because people have been so taken in by what is western. This sort of cultural imperialism, which seeks to enslave the African mind, has left in its wake a cultureless or culturally disoriented people ... Ugwueye (2007: p. 109).

Why won't the people be taken in by westernization when the only readily available form of cultural program is the Western ones? Globalization has always had a great impact on cultural identity. "Today, in an age when discrete cultures themselves are under threat, the question of cultural identity becomes newly problematic and takes on new urgency. The reason for this importance lies in the preservation of the traditional cultures and values that are carefully being sewn into the entanglements of globalization” Malgaj (2009).

How did globalization become so powerful to the extent of threatening national identities? The answer is in the massive flow of cultural products from developed country so much so that there is little or no room for indigenous cultural products in the cultural market. The resultant effect is cultural synchronization which invariably leads to identity loss of the recipients.

The picture of identity loss was captured by Umeogu \& Ojiakor (2012) in the following words:

Who am I? Who are we? This is the type of question that subsequent generations will ask if the rate of cultural dependency on foreign material is not checkmated. This situation will be an aftermath of the elimination of culture. When a country consciously or unconsciously loses its identifying traits, what will they become? If "A" ceases to 
be " $\mathrm{A}$ " or blends into " $\mathrm{B}$ ", what happens to " $\mathrm{A}$ " when it comes to sovereignty and location?

Explaining the reason for the above scenario is Okunna who observed that:

Whether through their importation of western media culture or through the barrage of western television culture which flows into their countries through Direct Broadcast Satellite (DBS) over which they have no control, developing countries are at the receiving end as alien cultures which are alienating their peoples from their own countries” (Okunna, 1999: p. 145).

Another contribution was from Chinnammai, S. (2005: p. 1) who asserted that ... It (globalization) reflects the effect on culture and brings about a new form of cultural imperialism. The rise of new cultural imperialism is shaping children, the future citizens of the world into "global citizens", intelligent people with a broad range of skills and knowledge to apply to a competitive, information based society.

One of such skills is the mastery of English language at the detriment of local languages. According to Malgaj (2009),

... what helps these processes is the global dominance of English. This factor has a big importance in the issue of cultural identity and globalization. The current era is one in which corporations are the central producers and distributors of cultural products. The vast majority of these products originate within the USA and other western countries. It is clearly the availability of cheap and rapid communication and knowledge of one common language that permits the phenomena of integration of international capital market. Knowledge of English gives people that chance to communicate with other human beings around the world.

Have you ever witnessed a scenario where the children of nowadays visit the villages? Communication is virtually impossible because they cannot understand what the villagers are saying and vice versa. There was this particular case where a grandmother told his son to take his children back to the city because there was no form of communication since the children only speak and understand English language. Any form of communication was possible if their parents were there to play an interpretative role. It sounds funny but that is how obsolete our native language is becoming.

\section{Non Appreciability of Culture}

Non appreciation of culture leads to loss of identity amongst other reasons. Identity shoots out from cultural beliefs and practices. In other words, when there is loss of cultural values, there is loss of identity. If that is the case, when one loses his/her identity and takes on another one, is it still a case of identity loss since there is something to be identified with? The question is vividly answered by Umeogu \& Ojiakor (2012) who submitted that 'If ' $A$ ' ceases to be ' $A$ ' or blends into ' $B$ ', what happens to ' $A$ ' when it comes to sovereignty and location? ' $A$ ' will no longer be in existence".

The truth is that many people especially the younger generation are not proud of their culture. It is not contestable that civilization has bettered the lives of people, but however, greed, materialism and inferiority complex is now threatening to drown our culture.

Look at a country like China, in the face of globalization; they are still proud of their dressing, food, language, mode of life. So much so that many Universities has created Confucius Institute where Chinese is learnt. If they were not proud of their identity, others will not have longed to be part of that heritage. Capturing the Chinese experience is Dukor, though referring to Africa, submitted that "across the length and breadth of African and African communities, there is that conscious and inexorable desire by the people to preserve their aboriginal cultures, retain their identity and live the authentic life...” (2007: p. vi).

Sadly, "in virtually every third world country, mass media audiences consume large quantities of foreign media culture. It is feared that this massive exposure to foreign culture could distort and displace native cultures in developing countries, Okunna, 1999 in Umeogu \& Ojiakor, 2012).

Well, it is no longer feared because it has finally happened. This thirst has done Nigerians more harm than good. There has been increase in crime, immorality, vices, lack of respect for elders and ways of life. In fact, Globalization is our doom. In the process of tearing down barriers in the areas of culture and economic, it also tore down the walls of morals and have thrown morality to the dogs. Immorality in the name of being compliant or westernized has become the order of the day. The bottom line is that the vices of the developed world have been imported into the developing world by globalization. Thomas Larsson states that globalization "is the process of world shrinkage, of distances getting shorter, things moving closer. It pertains to the increasing ease with which somebody on one side of the world can interact, to mutual benefit, with somebody on the other side of the world". What mutual benefits have Nigerians gotten from globalization as regards culture and identity?

In the original Nigerian culture, armed robbery, indecent dressing, single parenthood, prostitution was frowned upon, but in this borrowed robes we call westernization or civilization, it is seen as a way of life. Seeing such vices as a way of life could be traced to what is gotten from the media. As Okunna rightly observed;

... because mass communication is such a powerful vehicle for the dissemination of culture, there has always been fears that massive flow of foreign mass media contents into societies other than those in which such contents are produced, will negatively influence local culture (Okunna, 1999: p. 142).

\section{The Aftermath}

With the speed that Nigeria is fast losing her identity, what will be the fate of generations unborn? What will be taught during history lessons?

What will be our pride in the nearest future? Ugwueye (2007: p. 104) asserts that "Africans today, can rarely define the rules and regulations of their economy, production, credits and exchange of goods and services due to rampaging menace of globalization”. That is of today, what will be the situation in the next decade?

Another aftermath is the impoverishment of the people. Inferiority complex, greed and materialism have led to a situation where locally made goods are not appreciated at all. The result 
is a situation where the local firms and entrepreneurs are run out of business where foreign ones boom the market. Thereafter, the poor get poorer as there is no equal playing ground to compete with the foreign firms.

How do we even begin to talk on morality? Vices like materialism; disrespect for human life and dignity; organized crime; and Sexual perversion have become the order of the day all in the name of exercising fundamental human rights. Did our fore fathers not exercise their rights when it came to morality? They did. Nowadays, the definition of morality is quite distinct from what is now obtainable. And that is the reason why this paper maintains that the vices of the developed world have been imported into the developing world by globalization.

\section{Conclusion}

This paper does not mean to paint globalization as a monster. Rather, we wanted to point out that globalization, which ideally is meant to give people options and ideas to update their culture, has turned to be the fall of many cultures. This is because of the inequality in power structure among the global players; countries like Nigeria now found themselves at the receiving end where they are forced to join "them" since they cannot beat "them". The situation is worsened by the quantity of foreign cultural products consumed by the people; thereby further weakens their resolve sending the original cultures of the people into oblivion.

Every individual, society or nation is blessed and endowed with special qualities that should not be allowed to fade into oblivion because of the desire to homogenize with another culture. The fact that as it has been said that all fingers are not equal, so it is that all men, nations, societies are not equal. Nigerians in particular and African in general should understand that the fact that we are not equal with the western giants does not make us less a "finger". No matter our size and footing globally we should be proud of who we are.

This paper advises that people slow down in the consumption and thirst for foreign products and life so as to salvage our culture, our identity, our pride.

\section{REFERENCES}

Albrow, M., \& King, E. (1990). Globalization, knowledge and society. London: Sage.
Chinnammai, S. (2005). Effects of globalization on education and culture. ICDE International Conference, New Delhi, 19-23 November 2005.

Clayton, T. (2004). “Competing conceptions of globalization” revisited: Relocating the tension between world-systems analysis and globalization analysis. Comparative Education Review, 48, 274-294. doi:10.1086/421180

Dukor, M. (2010). African philosophy in the global village. Germany: Lambert Academic Publishing.

Giddens, A. (1991). The consequences of modernity. Cambridge: Polity Press.

http://www.brainyquote.com/quotes/keywords/globalisation.html http://www.buzzle.com

http://www.csus.edu/org/capcr/documents/archives/2006/conferencepro ceedings/kwame.pd

http://www.econ.cam.ac.uk/cjeconf/delegates/ibrahim.pdf

http://www.infed.org/biblio/globalization.htm

http://www.nai.uu.se/ecas-4/panels/21-40/panel-30/Asogwa-Felix-Chin we-Full-paper.pdf

http://www.uis.unesco.org/template/pdf/cscl/IntlFlows_EN.pdf

http://www.wikipedia.org/wiki/Globalization

Larsson, T. (2001). The race to the top: The real story of globalization. Washington DC: Cato Institute.

Malgaj, L. (2009). The impact of globalization on cultural identity. URL (last checked 23 June 2012). www.mystressmanagement.net

Ogugua, I., \& Oduah, I. (2007). Globalization and development: A philosophical viewpoint. Essence Interdisciplinary International Journal of Philosophy, 4, 1-24.

Okunna, C. (1999). Introduction to mass communication. Enugu: New Generation Books.

Robertson, R. (1992). Globalization: Social theory and global culture (Reprint ed.). London: Sage. doi:10.1177/026327692009002010

Scheuerman, W. (2010). Globalization. Stanford encyclopedia of Philosophy. http://plato.stanford.edu/

Scholte, J. A. (2000). Globalization. A critical introduction. London: Palgrave.

Smith, M. K., \& Doyle, M. (2002). Globalization. Encyclopedia of informal education. www.infed.org/biblio/globalization.htm

Stiglitz, J. (2002). Globalization and its discontents. London: Allen Lane.

Takis Fotopoulos (2001). Democracy \& nature. The International Journal of Inclusive Democracy, 7.

Ugwueye, L. (2007). The place of Africa in globalization. Essence Interdisciplinary International Journal of Philosophy, 4, 102-111.

Umeogu, B., \& Ojiakor, I. (2012). Cultural dependency: A philosophical insight. Open Journal of Philosophy, 2, 123-127.

Burton, R. (N/A). Globalisation and cultural identity in Caribbean society: The Jamaican case. www.ojs.mona.uwi.edu/index.php/ 